\title{
OPERATIONAL SPECIATION OF LEAD, CADMIUM, AND ZINC IN FARMLANDS AROUND A LEAD POLLUTED GOLDMINE IN NORTHERN NIGERIA
}

\author{
Ibrahim Mohammed and *Nafiu Abdu \\ Department of Soil Science, Ahmadu Bello University, PMB 1044, Samaru, Zaria-Nigeria \\ *Corresponding author: abdunafiu007@gmail.com; nabdu@abu.edu.ng
}

\begin{abstract}
This study was undertaken to evaluate the geochemical fractions and risk potential of lead $(\mathrm{Pb})$, cadmium $(\mathrm{Cd})$ and zinc $(\mathrm{Zn})$ in farmlands around a polluted goldmine in Dareta, northern Nigeria. The total heavy metal concentrations were obtained through a mixed acid digestion. A modified sequential extraction procedure was used in separating the total metal concentrations into five operationally defined fractions. The results showed extremely high concentrations of total $\mathrm{Pb}\left(26-2,247 \mathrm{mg} \mathrm{kg}^{-1}\right)$, and $\mathrm{Cd}\left(2-69 \mathrm{mg} \mathrm{kg}^{-1}\right)$ in the soils. The fractionation results also showed very high concentrations of $\mathrm{Pb}$ and $\mathrm{Cd}$ held on the easily mobilized fractions. However, in terms of proportions, the bulk of the metal concentrations were partitioned to the residual fraction while the exchangeable fraction held the least. The concentrations of $\mathrm{Zn}$ recorded were below the thresholds employed. Lead and $\mathrm{Cd}$, showed strong enrichment, with both elements recording enrichment factors of 32.8 and 83.0, and Igeo factors of 4.4 and 5.8, respectively. Although the bulk of the metals were partitioned to the residual fractions, the concentration of metals held onto the easily mobilized fractions such as the exchange, oxide and organically bound fractions may make the metals bioavailable on the long run with possible pollution risk on this soil, especially when used for agricultural purposes.
\end{abstract}

Keywords: Heavy metal contamination, Metal fractionation, Pollution index

\section{INTRODUCTION}

Anthropogenic activities such as agricultural and industrial waste materials (Abdu et al., 2011) mining/smelting/electroplating activities (Liu et al., 2007) have been reported as major source of heavy metal pollution. Metals in the soil environment undergo an array of biogeochemical processes at reactive natural surfaces, including surfaces of clay minerals, metal oxides and oxyhydroxides, humic substances, plant roots, and microbes. These processes control the solubility, mobility, bioavailability, and toxicity of metals in the environment. The soil is usually 
the final destination of metals emitted into the environment. The soil is a dynamic and complex system and any change in its intrinsic physicochemical properties would change the fate of metal pollutants in the soil system. When investigating soil pollution, the total heavy metal concentration in the soil solid fraction is not a good indicator of bioavailability (Abdu et al., 2012) because metals can be associated with various soil components such as organic matter, clays, $\mathrm{Fe}$ and $\mathrm{Mn}$ oxides, and the lattice of silicate or carbonate minerals which differs in their ability to retain or release metals (Shaheen and Rinklebe, 2014). Finding effective solutions to remediating heavy metal polluted lands centers on a clear understanding of the behavior of metals in the soil environment, particularly an understanding of the various reactions which metals undergo with soil solid phase. This is pertinent for soils of the variable charged soils of the tropic which are intrinsically different in reactions, and for which interpretations have always been based on observations made for temperate regions.

In the area where this study was carried out, artisanal mining has resulted in large scale pollution of the land. Gold ore is collected from mining sites outside the village which is bagged and brought to the village where it is washed over a ridge board. When the smallscale miners in this village grind ore from local gold mines filled $\mathrm{Pb}$, they spew Pb dust across the ground where children eventually play and animal grazes. The US Blacksmith institute reported some of the soils in these villages to contain up to $100,000 \mathrm{mgkg}^{-1}$ of $\mathrm{Pb}(\mathrm{BI}, 2010)$.

Heavy metals such as $\mathrm{Pb}, \mathrm{Zn}$ and $\mathrm{Cd}$ have been reported in some polluted lands close to the study area as a result of artisanal mining (Abdu and Yusuf, 2012). Hence this research was undertaken to achieve the following objectives:

1. To evaluate the geochemical distribution of $\mathrm{Pb}, \mathrm{Cd}$, and $\mathrm{Zn}$ in the soils of the farmlands surrounding the gold mines

2. To assess the level of heavy metal pollution of the soils of the farmlands; and

3. To evaluate the potential risk of heavy metal transfer to human as a result of mobility of $\mathrm{Pb}, \mathrm{Cd}$, and $\mathrm{Zn}$

\section{MATERIALS AND METHODS}

\section{Study area and sampling strategy}

The soils for the study were collected from Dareta village, northern Nigeria. Details of the study area and sampling procedure have been reported elsewhere (Mohammed and Abdu, 2014). Briefly, the climate of Zamfara is a Sudan savannah with a mean annual rainfall of 579 
$\mathrm{mm}$. The dominant soil type is a Typic Haplustalf, according to the USDA classification (Soil Survey Staff, 2010). Soil samples were taken at $0-20 \mathrm{~cm}$ depth on a grid at distances of 10 , $30,50,150,300,500$, and $1000 \mathrm{~m}$.

\section{Soil physical and chemical analyses}

Soil physical and chemical properties (Table 1) were determined using standard analytical procedures. Particle size distribution was determined by the hydrometer method (Gee and Or, 2002). Cation exchange capacity (CEC) was determined using ammonium acetate $\left(\mathrm{NH}_{4} \mathrm{OAc}\right)$ saturation method (Rhoades, 1982). Soil pH was measured in 1:2.5 soil/water suspensions. Electrical conductivity (EC) was determined using the Conductivity Measuring Bridge, Type M.C.S. Model EBB/10. Organic carbon (OC) was determined by the acid-dichromate wet oxidation method of Walkley and Black (Nelson and Sommers, 1982) and carbonate was determined by titration with $0.1 \mathrm{~N} \mathrm{NaOH}$. Total phosphorus $\left(\mathrm{P}_{\text {total }}\right)$ was determined by the method of Murphy and Riley (1962) following acid digestion.

Total concentration of $\mathrm{Pb}, \mathrm{Cd}$ and $\mathrm{Zn}$ in the soil was determined by Atomic Absorption Spectrometer (AAS) (Model AA 500, PG Instrument, U.K) following $\mathrm{HNO}_{3}, \mathrm{HF}$ and $\mathrm{HCl}$ digestion of a ground soil sample.

Table 1: Mean physicochemical properties of the soil of Dareta, northern Nigeria

\begin{tabular}{llllllllll}
\hline $\begin{array}{l}\text { Sampling } \\
\text { Direction }\end{array}$ & & $\mathrm{pH}$ & $\begin{array}{l}\mathrm{C}_{\text {org }} \\
\left(\mathbf{g ~ k g}^{-1}\right)\end{array}$ & $\begin{array}{l}\text { CEC } \\
\left(\mathrm{mmol}_{(+)} \mathbf{k g}^{-1}\right)\end{array}$ & $\begin{array}{l}\mathbf{P}_{\text {total }} \\
\left(\mathbf{g ~ k g}^{-1}\right)\end{array}$ & $\begin{array}{l}\text { Clay } \\
\left(\mathbf{g ~ k g}^{-1}\right)\end{array}$ & $\begin{array}{l}\text { Sand } \\
\left(\mathbf{g ~ k g}^{-1}\right)\end{array}$ & Texture \\
\hline Dareta North & $\mathrm{n}=7$ & 6.14 & 9.92 & 106 & 1.12 & 259 & 428 & Clay \\
Dareta South & $\mathrm{n}=7$ & 6.47 & 7.34 & 872 & 1.36 & 255 & 460 & Loam \\
Dareta East & $\mathrm{n}=7$ & 6.23 & 8.32 & 968 & 0.82 & 251 & 532 & Sandy loam \\
Dareta West & $\mathrm{n}=7$ & 6.39 & 5.28 & 804 & 0.61 & 285 & 463 & Clay Loam \\
\hline
\end{tabular}

The labile concentrations of $\mathrm{Pb}, \mathrm{Cd}$, and $\mathrm{Zn}$ were extracted by shaking $10 \mathrm{~g}$ soil with $20 \mathrm{~mL}$ of $0.01 \mathrm{M} \mathrm{CaCl}_{2}$ for $16 \mathrm{hrs}$ and concentration of $\mathrm{Pb} \mathrm{Cd}$, and $\mathrm{Zn}$ in the extract were determined in AAS. 


\section{Sequential Extraction}

The sequential extraction method modified from Tessier et al. (1979) was used to separate $\mathrm{Pb}, \mathrm{Cd}$ and $\mathrm{Zn}$ into 5 operationally defined fractions: exchangeable $\left(\mathrm{EXCH} ; 1 \mathrm{M} \mathrm{NH}_{4} \mathrm{OAc}\right.$ at $\mathrm{pH}$ 7.0), carbonate (CARB; $1 \mathrm{M} \mathrm{NaOAc}$ at $\mathrm{pH} 5.0$ ), Fe and Mn oxides (OX; $0.04 \mathrm{M}$ $\mathrm{NH}_{2} \mathrm{OH} . \mathrm{HCl}$ in acetic acid), organic matter $\left(\mathrm{OM} ; 0.1 \mathrm{~N} \mathrm{HNO}_{3}+30 \% \mathrm{H}_{2} \mathrm{O}_{2}\right)$, and residual (RES) fractions. The residual fraction was calculated as the difference between the concentration of total metal and the sum of the other four fractions.

$\mathrm{RES}=\mathrm{M}_{\mathrm{T}}-(\mathrm{EXCH}+\mathrm{CARB}+\mathrm{OX}+\mathrm{OM})$

$\mathrm{M}_{\mathrm{T}}=$ total metal concentration

The concentration of $\mathrm{Pb}, \mathrm{Cd}$, and $\mathrm{Zn}$ in solution of each fraction was determined in AAS (Model AA 500, PG Instrument, U.K).

\section{Data Analysis}

Analysis of variance (ANOVA) was used to determine the significant differences in total and extractable metal concentrations. The relationships among the various metal fractions and soil properties were determined using correlation analysis, and the sample means were compared using Fisher's Least Significant Difference $\left(\mathrm{LSD}_{0.05}\right)$. All statistical data analyses were performed using SAS Version 9.0 (SAS, 2002). Lead, Cd, and Zn mobility were assessed by the mobility index (MI) proposed by Liu et al. (2007):

$$
M I=\sum_{i=1}^{n} \frac{F_{i} / T_{i}}{n}
$$

Where $F_{i}$ is the metal concentration in the EXCH fraction, $T_{i}$, the total concentration of the metals, and $n$ is the number of the soil samples.

Metal enrichment factor (EF) for $\mathrm{Pb}, \mathrm{Cd}$ and $\mathrm{Zn}$ was calculated based on the following relation, as proposed by Sposito (2008):

$$
E F=\left(M_{\text {soil }}\right) /\left(M_{\text {earth crust }}\right)
$$

Where $M_{\text {soil }}$ is the metal concentration in the soil and Mearth crust is the average metal concentration in the earth crust, which is approximately $14.8,0.1$ and $65 \mathrm{mg} \mathrm{kg}^{-1}$ for Pb, Cd 
and $\mathrm{Zn}$ respectively (Sposito, 2008). The geoaccumulation index (I-geo), as proposed by Muller (1969), was calculated by computing the base 2 logarithm of the measured total concentration of the metal over its background concentration using the following mathematical relation (Muller, 1969; Ntekim et al., 1993):

$$
\text { I-geo }=\log _{2}(\mathrm{Cn} / 1.5 \mathrm{Bn})
$$

where $\mathrm{Cn}$ is the concentration of metal $\mathrm{n}$ in the soil, $\mathrm{Bn}$ is the soil background concentration of heavy metal $\mathrm{n}$ and 1.5 is a factor compensating the background data (correction factor) due to lithogenic effects.

\section{RESULTS AND DISCUSSION}

\section{Total Metal Concentration}

The total heavy metals concentration showed a very wide range, especially for $\mathrm{Pb}$ which was between $26 \mathrm{mgkg}^{-1}$ and $2247 \mathrm{mgkg}^{-1}$; Cd, 2 - $71 \mathrm{mgkg}^{-1}$ (Table 2). However, the concentration of $\mathrm{Zn}$ was within the contaminants thresholds of $200-300 \mathrm{mgkg}^{-1}$ used in evaluation (CCME, 2001). Both concentrations of $\mathrm{Pb}$ and $\mathrm{Cd}$ indicated extreme level of contamination of the soil matrix with concentrations far beyond the minimum acceptable values of $1.4-3 \mathrm{mgkg}^{-1}$ and $70-300 \mathrm{mgkg}^{-1}$ respectively in arable soils (CCME, 2001). Because the total concentration of metals are poor indices for assessing pollution risk, the partitioning of the metals within the soil matrix was evaluated (Figures 1-3). These results showed that the concentration of $\mathrm{Pb}$ held on each of the easily mobilized fractions (i.e exchangeable, carbonate, and organic matter) was below the contaminants thresholds employed. The fraction in which the above threshold concentrations were observed was the residual, these fractions are a more stable and not easily available to the biota (except through the slow process of weathering (Filguerias et al., 2002; Abdu et al., 2012). The concentrations of Pb held on the residual fraction were so high that it exceeded the sum of metals held on the other fractions, in most cases. The residual fraction represents metals associated with nonreactive silicate clay minerals. Going by the chemistry and behavior of metals held on the residual fraction, this observation could infer that these high $\mathrm{Pb}$ concentrations carries a low risk of metal transfer to growing plants; although this inference is not explicit and does not rule out risk of metal transfer because dust containing particles of contaminants could still be deposited on the plants, and when crops are harvested and taken home the risk of transferring such contaminants to the food chain is high. Hence the inference solely from the chemistry of the residual fraction is tenuous. 
With respect to the $\mathrm{Cd}$ concentrations, fractional concentrations were all below the contaminant threshold (Figure 2). However, because only a single reaction cannot be on going at any time within the soil system but a number of reactions happen concurrently, it is accurate to consider the concentrations of the easily mobilized fractions together. Upon adding up the concentrations of the Exchangeable, Carbonate and Organic matter fractions, the concentration of $\mathrm{Cd}$ derived were above the threshold concentration of $30 \mathrm{mg} \mathrm{kg}^{-1}$. These observations elevate the risk of $\mathrm{Cd}$ transfer to plants because the exchangeable metal fraction corresponds to the form of metals most available for plant uptake, and could easily be released following any change in the ionic strength of the soil solution medium (Filguerias et al., 2002). Although studies in temperate regions have shown metals held on the organic matter fractions to persist in the soil (Kennedy et al., 1997); the same inference cannot be extended to tropical soils due to the high degree of organic matter oxidation. In tropical soils, the oxidation of organic matter is an important process, hence metals held on this fraction are important sources of easily mobilized fractions (Filguerias et al., 2002). This observation places a lot of risk hazard from $\mathrm{Cd}$. Cadmium uptake and accumulation in plant tissue which is a common occurrence in soils with Cd enrichment (Abdu et al., 2011). Likewise, the health hazard from $\mathrm{Cd}$ ingestion can be horrible making the risk of $\mathrm{Cd}$ in these soils very high most especially with children through pica and dust inhalation.

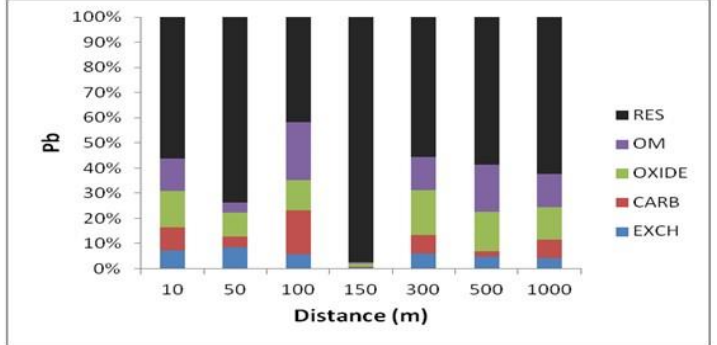

Figure 1: The proportional percentage of $\mathrm{Pb}$ in a heavy metal contaminated soil in Dareta, northern Nigeria

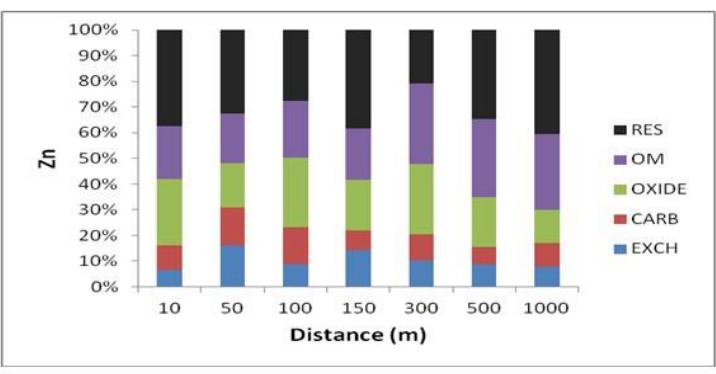

Figure 3: The proportional percentage of $\mathrm{Zn}$ in a heavy metal contaminated soil in Dareta, northern Nigeria

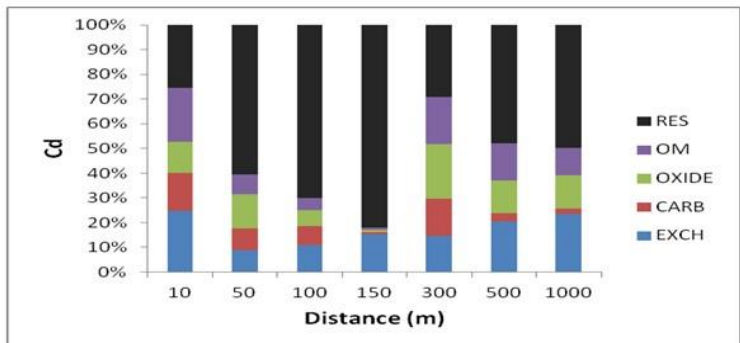

Figure 2: The proportional percentage of $\mathrm{Cd}$ in a heavy metal contaminated soil in Dareta, northern Nigeria 
Table 2: Range, mean concentration, and standard error of $\mathrm{Pb}, \mathrm{Cd}$, and $\mathrm{Zn}$ in the soils of the study

\begin{tabular}{|c|c|c|c|}
\hline $\begin{array}{l}\text { Sampling } \\
\text { Direction }\end{array}$ & $\begin{array}{c}\mathrm{Pb} \\
(\mathrm{mg} \mathrm{kg}-1)\end{array}$ & $\begin{array}{c}\mathrm{Cd} \\
\left(\mathrm{mg} \mathrm{kg}^{-1}\right)\end{array}$ & $\begin{array}{c}\mathrm{Zn} \\
(\mathrm{mg} \mathrm{kg}-1)\end{array}$ \\
\hline Dareta North $\quad n=7$ & $\begin{array}{c}25.95-523.5 \\
(381 \pm 138.16 \mathrm{c})\end{array}$ & $\begin{array}{c}16.8-68.7 \\
(27.76 \pm 10.19 b)\end{array}$ & $\begin{array}{c}97-295 \\
(172.77 \pm 33.37 b)\end{array}$ \\
\hline $\begin{array}{l}\text { Dareta South } \\
n=7\end{array}$ & $\begin{array}{c}190.2-717.15 \\
(424.2 \pm 113.15 b)\end{array}$ & $\begin{array}{c}16.8-70.5 \\
(40.68 \pm 11.05 a)\end{array}$ & $\begin{array}{c}95-374 \\
(193.98 \pm 47.60 a)\end{array}$ \\
\hline $\begin{array}{l}\text { Dareta East } \\
n=7\end{array}$ & $\begin{array}{c}180.75-1497 \\
(578.88 \pm 243.87 a)\end{array}$ & $\begin{array}{c}16.65-62.4 \\
(39.48 \pm 10.13 a)\end{array}$ & $\begin{array}{c}88.65-330 \\
(154.56 \pm 44.65 c)\end{array}$ \\
\hline $\begin{array}{l}\text { Dareta West } \\
n=7\end{array}$ & $\begin{array}{c}35.1-2246.55 \\
(555.69 \pm 295.98 a)\end{array}$ & $\begin{array}{c}1.85-21.45 \\
(15.94 \pm 0.79 c)\end{array}$ & $\begin{array}{c}66.45-244.5 \\
(145.5 \pm 7.20 c)\end{array}$ \\
\hline
\end{tabular}

Means followed by the same letters are not statistically different at $5 \%$ probability level; threshold values for $\mathrm{Cd}$ (1.4-3); $\mathrm{Pb}$ (70-300) and $\mathrm{Zn}$ (200-300) all in $\mathrm{mgkg}^{-1}$ (CCME, 2001).

Considering the pedology of the bottom horizons of this soil (the occurrence of hard pans at the bottom horizon) redox changes is an important reaction under very high rainfall. The onset of redox conditions following water logging of the bottom horizon after a heavy rainfall is an accurate assumption. This possibility places importance on the metals held on the oxide fractions because the oxide bound fractions are thermodynamically unstable under anoxic conditions (Filguerias et al., 2002). Cadmium held on the fractions of Fe and Mn oxides would be desorbed under this condition. This condition would only complicate the risk of pollution from Cd.

The concentrations of $\mathrm{Zn}$ recorded in the soils were below threshold concentration (Table 2), thus overruling any possible health risk hazard from $\mathrm{Zn}$.

\section{Distribution patterns of heavy metals in the soil matrix}

The pattern of distribution of the metals was shown as percentages of the total concentration based on results from the fractionation procedure. The bulk of the total concentrations of $\mathrm{Pb}$ were held on the residual fractions (Figure 1). The relatively high percentage of the residual fractions is suggestive of the origin of the contaminant, lithogenically derived (Malandrino et 
al., 2011). Although there exists the likelihood of anthropogenically introduced metal transformed into residual metals as a result of aging, this likelihood was not important in this study, because any anthropogenically deposited contaminant originated from the metal ores processed in the village. In some of the samples, as high as $89 \%$ of the total $\mathrm{Pb}$ concentrations were bound to the residual fractions. The exchangeable fraction of the soil held the least percentage $(2-6 \%)$ of the total $\mathrm{Pb}$ concentration recorded.

While about $25 \%$ of the total $\mathrm{Pb}$ concentrations were held onto the organic matter fraction. The proportion of metal on the carbonate fractions ranged from $1.6 \%$ to $18.2 \%$ of the total $\mathrm{Pb}$ concentration. The bulk of the total $\mathrm{Cd}$ was partitioned to the residual fraction (36-62 \% of the total $\mathrm{Cd}$ ), followed by the exchangeable fraction which held $11-16 \%$ of total $\mathrm{Cd}$ (Figure 2). However, the distributions of $\mathrm{Cd}$ among the oxide, $\mathrm{OM}$ and carbonate fractions were similar to those of $\mathrm{Pb}$. The carbonate bound $\mathrm{Cd}$ was lower than that of $\mathrm{Pb}$ for the whole study area, however the oxide bound fraction was next to the residual and exchangeable. The percentage of $\mathrm{Cd}$ partitioned to the oxide fraction ranged from $2 \%$ to $5 \%$ for the whole study area.

Organically bound fraction of $\mathrm{Zn}$ accounted for $17-25 \%$ of total $\mathrm{Zn}$ (Figure 3). The oxide fraction accounted for $31-55 \%$ of the total $Z n$ concentration. However, the relatively higher proportion of residual fractions of $\mathrm{Zn}$ is similar to the observations for $\mathrm{Pb}$ and $\mathrm{Cd}$, and it further suggest a lithogenic origin of $\mathrm{Zn}$ in these soils.

\section{Correlation between metal fractions}

Significant positive correlation was observed between the exchangeable $\mathrm{Cd}$ fractions and carbonate bound $\mathrm{Cd}$ fractions; similar levels of correlation were also observed between the exchangeable $\mathrm{Cd}$ and the oxide and residual $\mathrm{Cd}$ fractions (Table $3 ; \mathrm{p} \leq 0.05$ ). This suggests a strong buffering of the exchangeable $\mathrm{Cd}$ concentration by the oxide, carbonate and residual fractions, thereby increasing the risk of $\mathrm{Cd}$ release into the environment. However, only the residual and oxide bound fractions were positively correlated for $\mathrm{Zn}$ (Table 6). This could imply that similar processes are most likely controlling $\mathrm{Zn}$ release from both fractions and a possible transformation of $\mathrm{Zn}$ from the residual to a more mobile carbonate-bound fraction. No significant correlation was observed between the fractions of $\mathrm{Pb}$. 


\section{Enrichment and accumulation of $\mathrm{Pb}, \mathrm{Cd}$ and $\mathrm{Zn}$}

The EF is the ratio of soil to crustal rock concentration of an element. It gives a quantitative measure of the relative enrichment (or depletion) of an element in soil as compared with rock. Sposito (2008) gave metal enrichment factor values of between 2 and 10 as indication of some enrichment of the element under consideration while EF values of $<0.5$ and $>10$ would indicate significant depletion and strong enrichment respectively.

Table 3: Correlation coefficient matrix between the different $\mathrm{Cd}$ and $\mathrm{Zn}$ fractional concentration

\begin{tabular}{llllll}
\hline & EXCH & CARB & OXIDE & OM & RES \\
\hline EXCH & 1 & 0.34 & 0.25 & 0.31 & 0.68 \\
CARB & $0.96^{*}$ & 1 & 0.63 & 0.15 & 0.42 \\
OXIDE & $0.90^{*}$ & $0.85^{*}$ & 1 & 0.62 & $0.85^{*}$ \\
OM & 0.72 & 0.83 & 0.41 & 1 & 0.45 \\
RES & $0.88^{*}$ & 0.81 & 0.60 & 0.77 & 1 \\
\hline $\begin{array}{l}\text { The lower left-hand section is correlation coefficient for Cd while the upper, right-hand part is } \\
\text { correlation coefficient for } \mathrm{Zn} \text {; }{ }^{*} \text {, Significant at } \mathrm{p} \leq 0.05\end{array}$
\end{tabular}


Table 4: Average and background concentration, enrichment factor, calculated I-geo index, and grade of pollution intensity of $\mathrm{Pb}, \mathrm{Cd}$ and $\mathrm{Zn}$ in the soils Dareta

\begin{tabular}{|c|c|c|c|c|c|c|c|}
\hline $\begin{array}{l}\text { Heavy } \\
\text { metal }\end{array}$ & & $\begin{array}{l}\text { Average } \\
\text { value } \\
\left(\mathrm{mg} \mathrm{kg}^{-1}\right)\end{array}$ & $\begin{array}{l}\text { *Background } \\
\text { Concentration } \\
\left(\mathrm{mg} \mathrm{kg}^{-1}\right)\end{array}$ & EF & l-geo & $\begin{array}{l}\text { I-geo } \\
\text { grade }\end{array}$ & Pollution intensity \\
\hline $\mathrm{Pb}$ & $n=28$ & 491.3 & 15 & 32.8 & 4.4 & 5 & $\begin{array}{l}\text { Strongly/extremely } \\
\text { contaminated }\end{array}$ \\
\hline $\mathrm{Cd}$ & $n=28$ & 16.6 & 0.2 & 83 & 5.8 & 6 & $\begin{array}{l}\text { Extremely } \\
\text { contaminated }\end{array}$ \\
\hline $\mathrm{Zn}$ & $n=28$ & 164.8 & 80 & 2.4 & 1.8 & 1 & $\begin{array}{l}\text { Uncontaminated to } \\
\text { moderately } \\
\text { contaminated }\end{array}$ \\
\hline
\end{tabular}

*Lindsay (1979)

The calculated metal EF for $\mathrm{Pb}$ for the soils of Dareta ranged from 25.4 to 37.4 across the study area. This means that there is a strong superficial enrichment of the element as a result of anthropogenic activities. Similar observation was made for $\mathrm{Cd}$. The metal gave EFs between 79.7 and 203, while $\mathrm{Zn}$ only indicated some level of enrichment compared to the average rock concentration. The calculated values for $\mathrm{Zn}$ ranged from 1.8 to 2.4 (Table 4).

The calculated I-geo for the soils of this study ranged from 0.2 to 6.1 for $\mathrm{Pb} ; 3.2$ to 7.8 for $\mathrm{Cd}$; and -0.1 to 1.4 for $\mathrm{Zn}$. These indices were interpreted according to the index of geochemical accumulation with Igeo-class ranging from $0-6$ with 0 denoting no contamination and 6 denoting extremely contaminated. The values reported in this study reflect a 100 -fold metal concentration relative to background values. Although EF and I-geo allow for quick inferences on the status of a metal relative to mean soil and lithosphere concentration, they are not sufficient indicator for pollution risk; this is because they suffer from specificity in differentiating readily available and strongly bound metals. Rather it relies solely on total metal concentration, which is a poor indicator of pollution. At best, they give hints on the soils buffering capacity (replenishment) for the contaminants of interest. A summary of the mean $\mathrm{Pb}, \mathrm{Cd}$, and $\mathrm{Zn}$ concentration including their EF and I-geo index is presented in Table 4. 
A more reliable indicator is the mobility index which considers the weakly adsorbed fractions alone, following a sequential extraction (fractionation) procedure. For these soils, the calculated mobility indices showed $\mathrm{Zn}$ to be the most mobile element in the study area, followed by $\mathrm{Cd}$. Lead, which recorded the highest total metal concentration, was the least mobile. This finding assert that the mobility index has a more accurate inference on the mobility of these metals as its results are closely related to the fractionation results that allotted highest proportion of all the elements studied to the residual fraction. The mobility index (Liu et al. 2007; Banat et al., 2003) was used as a more accurate prediction of the risk of contaminant transfer to the food chain or ground water. The calculated mobility indices for the metals under study ranged from $0.46-1.76$ for $\mathrm{Pb}$; 3.21-3.66 for $\mathrm{Cd}$; and 1.01-3.99 for $\mathrm{Zn}$ (Figure 4). These values showed that $\mathrm{Zn}$ was the most mobile in the soil. Lead was the least mobile of the three studied metals. The observed order of mobility was $\mathrm{Zn}>\mathrm{Cd}>\mathrm{Pb}$. Although low concentration of $\mathrm{Cd}$ and $\mathrm{Zn}$ were observed to be associated with the available pools, their high mobility indices would reflect potential risk of pollution through leaching and plant uptake of metals.

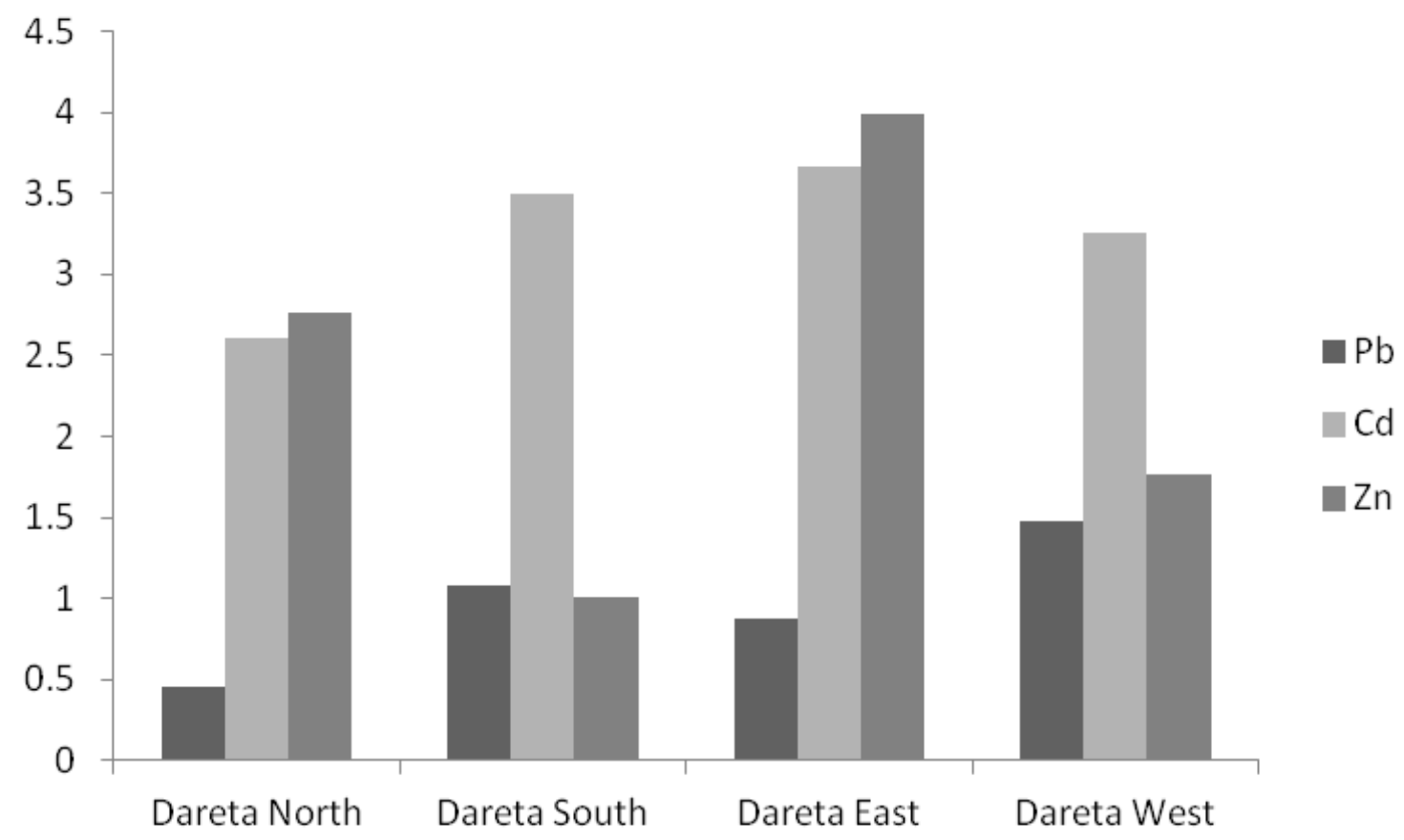

Figure 4: Mobility indices for $\mathrm{Pb}, \mathrm{Cd}$, and $\mathrm{Zn}$ along the sampled coordinates in Dareta, northern Nigeria 


\section{CONCLUSION}

Although the concentrations of $\mathrm{Pb}$ and $\mathrm{Cd}$ in the soils were very high, the fractional concentrations only placed high risk of contaminants transfer to the food on $\mathrm{Cd}$. The high levels of enrichment calculated from the contamination indices only indicate the buffering of soil solution metal concentration through the slow process of weathering. The calculated mobility indices for the three elements were also too low to warrant any major concern of metal transfer to the food chain, except for $\mathrm{Cd}$. With the exception of $\mathrm{Cd}$, the observations from this study reflect that, except in geological time, the total metal concentrations recorded would not play a significant role with respect to plant growth or in terms of most environmental processes. We thus, recommend that further studies be carried out to assess possible accumulation of these metals by crop plants within the vicinity of the goldmine. Legislation on artisanal mining is needed to curtail the menace of soil and environmental pollution.

\section{REFERENCES}

Abdu, N., Abdulkadir, A., Agbenin, J.O., Buerkert, A. (2011). Vertical distribution of heavy metals in wastewater-irrigated vegetable garden soils of three West African cities. Nutrient Cycling in Agroecosystem 89: 387-397.

Abdu, N., Agbenin, J.O., Buerkert, A. (2012). Fractionation and mobility of cadmium and zinc in urban vegetable gardens of Kano, northern Nigeria. Environmental Monitoring and Assessment 184: 2057-2066.

Abdu, N., Yusuf, A.A. (2012). Heavy metal contamination of soil and crop, and human health impacts in a contaminated village around gold mine in Zamfara state. Paper presented at the 46th Annual Conference of the Agricultural Society of Nigeria, Kano, Nigeria 5-9 November.

Banat, K.M., Howarib, F.M., Al-Hamad, A.A. (2003). Heavy metals in urban soils of central Jordan: Should we worry about their environmental risks? Environmental Research 97: 258-273.

Blacksmith Institute (BI), (2011). Environmental remediation- lead poisoning in Zamfara. 2010-2011 final report: UNICEF Programme Cooperation Agreement. 
[CCME] Canadian water quality guidelines for the protection of aquatic life: Summary Table. 2001. Winnipeg, Canada.

Filguerias, A.V., Lavilla, I., Bendicho, C. (2002). Chemical sequential extraction for metal partitioning in environmental solid samples. Journal of Environmental Monitoring 4: 823-857.

Gee, G.W., Or, D. (2002). Particle-size analysis. In: Dane, J.H., Topp, G.C. (Eds). Methods of Soil Analysis, Part 4: Soil Science Society of America Book Series No. 5/ Soil Science Society of America, pp 255-293. Madison, Wisconsin.

Kennedy, H.V., Sanchez, A.L., Oughton, D.H., Rowland, A.P. (1997). Use of single and sequential chemical extractants to assess radionuclide and heavy metal availability from soils for root uptake. Analyst 122: 89R-100R

Lindsay, W.L. (1979). Chemical equilibria in soils. John Wiley and Sons. New York.

Liu, J., Duan, C.Q., Zhu, Y., Zhang, X. Wang, C. (2007). Effect of chemical fertilizers on the fractionation of $\mathrm{Cu}, \mathrm{Cr}$ and $\mathrm{Ni}$ in contaminated soil. Environmental Geology 52: 1601-1606.

Malandrino, M., Abollino, O., Buoso, S., Giacomino, A., La Gioia, C., Mentasti, E. (2011). Accumulation of heavy metals from contaminated soil to plants and evaluation of soil remediation by vermiculite. Chemosphere $82: 169-178$

Muller, G. (1969). Index of geo-accumulation in sediments of the Rhine River. Geology 2: 108-118.

Mohammed, I., Abdu, N. (2014). Horizontal and vertical distribution of $\mathrm{Pb}, \mathrm{Cd}$ and $\mathrm{Zn}$ in farmlands around a contaminated goldmine in Zamfara, northern Nigeria. Archives of Environmental Contamination and Toxicology. 66 (2): 295-302.

Murphy, J., Riley, J.P. (1962). A modified single solution for the determination of phosphate in natural waters. Analytical Chemica Acta 27: 31-36.

Nelson, D.W., Sommers, L.M. (1982). Total carbon, organic carbon and organic matter. In. D.L. Sparks (Ed). Methods of Soil Analysis Part 2. Chemical Methods, pp $961-$ 1010. 
Ntekim, E.E., Ekwere, S.J., Ukpong, E.E. (1993). Heavy metal distribution in sediments from Calabar river southeastern Nigeria. Environmental Geology 21: 237-241.

Rhoades, J.D. (1982). Cation Exchange Capacity. In: Page, AL, Miller, RH, editors. Methods of Soil Analysis. Part 2. Chemical and Microbiological Properties. Soil Science Society of America. Madison, WI.

[SAS] Statistical Analysis System (SAS) Version 9.0. (2002). Users guide Inst. Cary, NC.

Shaheen, S.M., Rinklebe, J. (2014) Geochemical fractions of chromium, copper, and zinc and their vertical distribution in floodplain soil profiles along the Central Elbe River, Germany, Geoderma 228: 142-159

Soil Survey Staff (2010). Keys to Soil Taxonomy. 11 th edition. Washington, DC, USA: United States Department of Agriculture, Natural Resources Conservation Service.

Sposito, G. (2008). The Chemistry of Soils. 2nd Ed. New York: Oxford University Press

Tessier, A., Campbell, P.G.C., Bissom, M. (1979). Sequential extraction procedure for the speciation of particulate trace metals. Analytical Chemistry 51: 844-850. 